\title{
Geospatial and Multivariate Statistical Interpretations for Relationships between Physico-Chemical Properties and Heavy Metals in Some Agricultural Soils of Kalar and Quratoo Sub-Districts, East Iraq
}

\author{
Hayder Mohammed Issa ${ }^{1} \&$ Azad H. Alshatteri ${ }^{2}$ \\ ${ }^{1}$ Department of Chemistry, College of Science, University of Garmian, Sulaimaniyah, Iraq \\ ${ }^{2}$ Chemistry Department, Education College, University of Garmian, Sulaimaniyah, Iraq \\ Correspondence: Hayder M. Issa, University of Garmian, Sulaimaniyah, Iraq. \\ Email: hayder.mohammed@garmian.edu.krd
}

Doi: 10.23918/eajse.v6i1p39

\begin{abstract}
In this study, ninety agricultural soil samples were collected from Kalar and Quratoo subdistricts east of Iraq. Where soil samples have been analyzed to quantify concentrations of nine soil physicochemical properties and sixteen heavy metals by using ICP-OES with other analyzing tools. Analysis results showed that significant variations exist in concentrations of the investigated parameters among sampling sites. Multivariate statistics have been conducted to identify relationships between heavy metals and soil properties. Multiple correspondence analysis MCA showed strong relationships for total nitrogen T.N. with $\mathrm{Cu}, \mathrm{Ni}$, and $\mathrm{Hg}$. Agglomerative hierarchical clustering (AHC) and factorial analysis (FA) divided soil property relationships with heavy metals into three main categories in terms of heavy metals nature; naturally occurred, generated from anthropogenic sources, and of weak relationships. Spatial variation map showed that soil properties in middle parts of the study area are more impacted by heavy metals that came from anthropogenic sources. This study aids to improve the environmental protection and monitoring of agricultural lands in Iraq.
\end{abstract}

Keywords: Heavy Metals, Soil Contamination, Soils Properties, Multivariate Statistics, Spatial Distribution

\section{Introduction}

Studies on spatial variation and distribution of soil properties have a long tradition in land use planning (Castrignanò, Giugliarini, Risaliti, \& Martinelli, 2000). There were growing demands for information on the physical-chemical properties of soil to assist in establishing consistent plans in environmental, and natural sources management for any land (Budak, 2018). The field of environmental management for land has gradually broadened in performing of such environmental plans of land-use sustainability (Galford, Soares-Filho, \& Cerri, 2013). Most of the studies have indicated that traditional ways of soil survey are incompetent in presenting the necessary information of soil properties, due to differences among areas, even in the same country (Lagacherie \& McBratney, 2006). Precise and accurate data on soil properties in agricultural and rural areas is always curial in spatial distribution of those properties, and therefore it is considered as a key factor in promoting agricultural land sustainability (Usowicz \& Lipiec, 2017).

Excessive application of fertilizers and pesticides in agriculture led to the wide existence of heavy metals in agricultural soils (Khalifa \& Gad, 2018; Savci, 2012). The main problem about existence of heavy metals in agricultural soils is that the life-threatening consequences of high concentrations of such metals on human health. This risk is mainly generated from crop uptake for heavy metals, putting consumer's life and health at serious risk (Davies, 1992). Heavy metals usually tend to create relationships with the physical, chemical, and biological properties of agricultural soils (Chen \& $\mathrm{Pu}$, 
2007; KavitaVerma \& Pandey, 2019). Various studies on soil property relationships with heavy metals have applied statistical analysis methods to explain the spatial variation of these relationships for agricultural soils (Uchimiya, Klasson, Wartelle, \& Lima, 2011). Multivariate and geospatial statistics are mostly used for explaining the spatial relationships of physicochemical properties with heavy metals. The geostatistical Kriging and Inverse distance weighted IDW interpolations have been commonly used to detect the spatial behavior of soil properties and their relationships with heavy metals (Bhunia, Shit, \& Maiti, 2018; Shit, Bhunia, \& Maiti, 2016; Valladares, Camargo, Carvalho, \& Silva, 2009). At the same time as correlation matrix CM, agglomerative hierarchical clustering AHC, canonical correlation analysis CCorA, and principal component analysis PCA are widely utilized to display spatial correlations of agricultural soil attributes and heavy metals (Gutiérrez et al., 2016; Sungur, Soylak, \& Ozcan, 2014; Vega, Covelo, Andrade, \& Marcet, 2004).

There is no previous research on the spatial distribution of heavy metals relationships with agricultural soil physicochemical properties in Iraq and, more specifically, for Kurdistan region, where the study area of Kalar and Quratoo sub-districts is located. Most probably the conflicts and unusual current political circumstances in Iraq led to this gap and lack of needed studies in the past decades. However, only a few studies have been made for heavy metals in soils of Iraq, but no previous study has investigated the spatial relationships of these heavy metals with soil properties. The study area of Kalar and Quratoo sub-districts primarily comprises of cultivated agricultural and arable lands, where many strategic crops are produced.

It is of interest to know the spatial variation for the relationship of heavy metals with soil properties in this important agricultural area. The current study aims to determine and assess the spatial variation of relationships between some significant physicochemical properties with heavy metals in agricultural soils of Kalar and Quratoo sub-districts using various reliable geostatistical and multivariate statistical techniques. The main contribution made by this work will be the wide applicability in land sustainability for crop production in the concerned study area.

\section{Materials and Methods}

\subsection{Description of the Study Area}

The study area of Quratoo and Kalar sub-districts $\left(34^{\circ} 51^{\prime} 32^{\prime \prime} \mathrm{N}, 45^{\circ} 10^{\prime} 37^{\prime \prime} \mathrm{E}, 34^{\circ} 24^{\prime} 54^{\prime \prime} \mathrm{N}, 45^{\circ}\right.$ $45^{\prime} 7^{\prime \prime}$ E) is located in eastern Iraq, has a higher altitude of $200 \mathrm{~m}$ a.s.l, and covers an area about 1000 $\mathrm{km}^{2}$ of mostly arable lands. The population in the area has expanded in the last twenty years due to both economic growth and political situation in Iraq (Kurdistan Region Statistics/ Garmian Office, 2018). The annual rainfall of the area is $273 \mathrm{~mm}$ with no precipitation in the summer season (Garmian Region Agriculture Department, 2017). The winds are mostly northwesterly and in summer season southeasterly winds considerably occur with a possibility of dust storms generation (Iraqi Meteorological Organization and Seismology, 2010). The physical feature of the study area is comprising of plain and hilly areas. The area is dominantly covered by soils belong to Quaternary alluvial deposits. Soils of the study are physically categorized into four main classes: shallow soil; stony soil; chestnut soil, and rough cracked soil (Buringh, 1960). Geologically, the area is a semiarid region, that is dominantly covered by soils belong to Quaternary deposits (Muhaimeed, Saloom, Saleim, \& Alaane, 2014). 


\subsection{Soil Sample Collection and Preparation}

In this work, a total of ninety samples were taken at different depths from the surface $(0,10$, and 20 $\mathrm{cm}$ ) from thirty sites (three samples for each site), 14 from Quratoo sub-district and 16 from Kalar sub-district, within agricultural areas in the study area in June and July 2019. The basis of choosing the sampling locations is to cover most of the agricultural areas in the Quratoo and Kalar subdistricts (Figure 1). All sampling sites (S1 to S30) are away from roads with at least $200 \mathrm{~m}$. For each sampling site, the three collected samples at different depths, $250 \mathrm{~g}$ for each, were mixed into one composite sample. A wooden shovel has been used to take soil samples. The soil samples were then put in sealed plastic bags and taken to the laboratory for analysis.

At the laboratory of instrumental analytical chemistry (University of Garmian), the collected samples were preliminarily dried at a temperature of $60{ }^{\circ} \mathrm{C}$ for 2 hours to sieve them through a 2-mm mesh to remove any probable large particle and impurities that could be collected with the samples. After that, the sieved soil samples were packed in clean plastic bags and preparing them for chemical analysis.

\subsection{Laboratory Analysis for Soil Samples}

In each soil sample, concentrations for heavy metals of $\mathrm{Al}, \mathrm{As}, \mathrm{Ba}, \mathrm{Cd}, \mathrm{Co}, \mathrm{Cr}, \mathrm{Cu}, \mathrm{Fe}, \mathrm{Hg}, \mathrm{Li}, \mathrm{Mn}$, $\mathrm{Ni}, \mathrm{Pb}, \mathrm{Sr}, \mathrm{V}$, and $\mathrm{Zn}$ and for chemical exchangeable cations of $\mathrm{Ca}, \mathrm{K}, \mathrm{Na}, \mathrm{Mg}$, and total $\mathrm{N}$, with available P. acidity $\mathrm{pH}$, soil organic matter SOM and electrical conductivity EC have been quantified. Analysis has been performed using inductively coupled plasma optical emission spectroscopy ICP-OES (Spectro across Germany), according to a procedure of wet digestion for soil samples. Regarding heavy metals, soil samples were dried at $100{ }^{\circ} \mathrm{C}$ for 2 hours, and then samples were cooled and digested with concentrated nitric acid. All the samples have been analyzed within 24 hours from sampling time. A serial of dilution with $1000 \mathrm{mg} / \mathrm{l}$ was employed for standard solutions preparation. Standard solutions were diluted by several dilutions into 0, 0.1, 0.5, $2 \mathrm{ppm}$ in $0.5 \%$ nitric acid as diluent. For exchangeable cations concentrations, $\mathrm{Ca}, \mathrm{K}, \mathrm{Mg}, \mathrm{Na}$, and $\mathrm{P}$, samples were first extracted with $1 \mathrm{~N}$ ammonium acetate solution, neutral $\mathrm{pH} \mathrm{7,} \mathrm{and} \mathrm{then} \mathrm{measured} \mathrm{by} \mathrm{ICP-}$ OES. In all analysis steps, distilled deionized water and glassware washing were used for the dilutions.

Soil $\mathrm{pH}$ and soil electrical conductivity EC were measured using $\mathrm{pH}$ meter and conductivity meter, respectively, in a soil-water suspension of 1:2 (w/v), after waiting for a half-hour to achieve equilibrium state (Behera \& Shukla, 2015). organic matter (OM) content was determined using the dry ashing method of the Walkley-Black method (Storer, 1984). Total nitrogen has been identified using the Kjeldahl method (Bremner \& Mulvaney, 1983). To confirm the validation of analysis results, three replications were performed for each sample. 


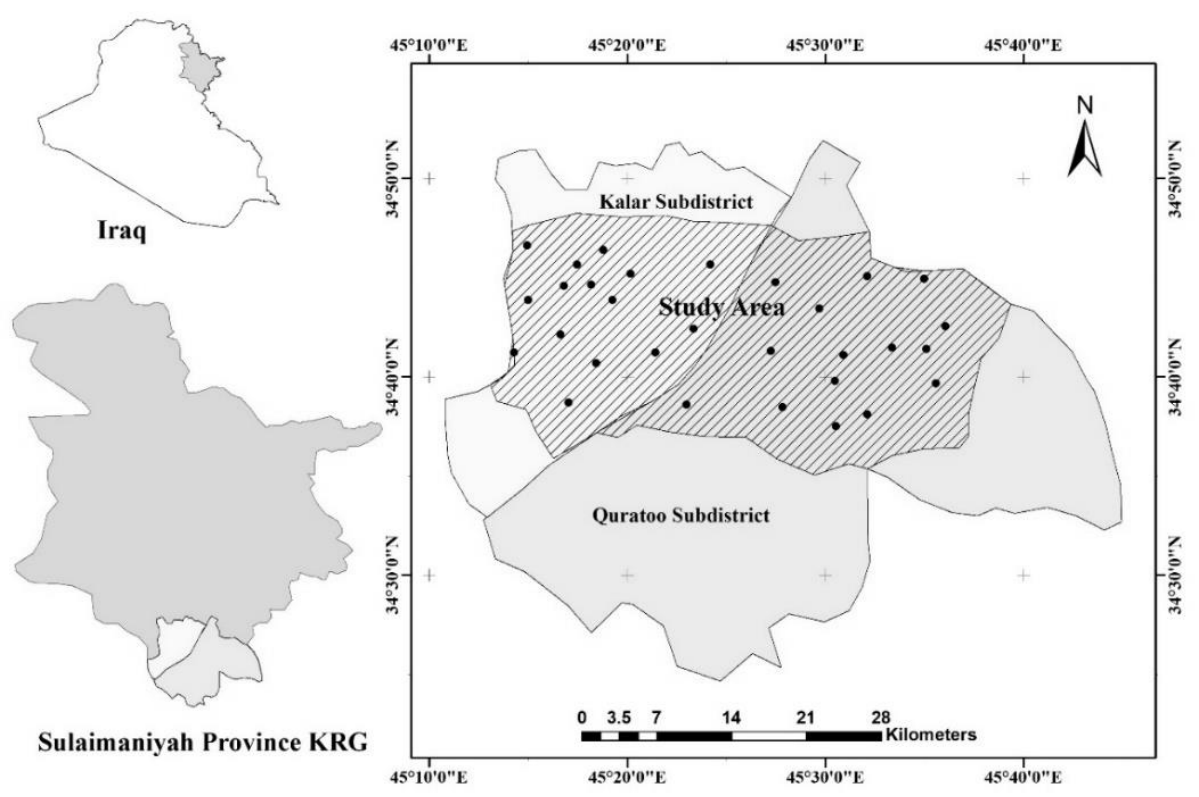

Figure 1: The study area showing sampling locations

\subsection{Statistical Analysis and Spatial Distribution}

In this paper, diverse descriptive and multivariate statistics were employed to interpret the soils dataset: Pearson correlation matrix CM, Agglomerative hierarchical clustering AHC, factorial analysis FA, and multiple correspondence analysis MCA. In similar cases of soil contamination assessment, multivariate statistics are broadly conducted. Pearson correlation matrix CM was commonly used to recognize relationships among tested soil property parameters. Whereas AHC, MCA, and FA are generally applied to classify the dataset into several main classes in order to distinguish individual impacts on the observations by created independent factors. FA exhibits loading weights of each extracted factors on the dataset, and also the loading weights of variables on each factor. The multivariate statistics were performed using the XLSTAT software, version 2017 for Excel 2013.

Furthermore, in the current study, geostatistics of ArcGIS software (version 10.6.1) was used to display the intensities of the heavy metals' relationships with soil properties. ArcGIS 10.6 (Kriging interpolation) was conducted to determine the spatial distribution of these relationships' variation in the study area.

\section{Results and Discussion}

\subsection{Descriptive Statistics of Physicochemical Soil Properties and Heavy Metals}

Table 1 presents the descriptive statistics of the physicochemical parameters and heavy metal concentrations samples from thirty different sites in the study area. In this study, 16 heavy metals of $\mathrm{Al}, \mathrm{As}, \mathrm{Ba}, \mathrm{Cd}, \mathrm{Co}, \mathrm{Cr}, \mathrm{Cu}, \mathrm{Fe}, \mathrm{Hg}, \mathrm{Li}, \mathrm{Mn}, \mathrm{Ni}, \mathrm{Pb}, \mathrm{Sr}, \mathrm{V}$, and $\mathrm{Zn}$ have been analyzed, and 8 physicochemical parameters of $\mathrm{Ca}, \mathrm{K}, \mathrm{Na}, \mathrm{Mg}$, total $\mathrm{N}, \mathrm{pH}, \mathrm{OM}$ and $\mathrm{EC}$ in each soil samples were examined.

Descriptive statistics were calculated for all parameters used in the study using the percentage of the coefficient of variation $\mathrm{CV} \%$, which is performed to define data variability, demonstrates a moderate 
variation. For a CV\% scale ranges between 10 and 100, in this work, CV\% results for the heavy metals varied from 3.5 to $24.95 \%$ of $\mathrm{Mn}$ and $\mathrm{Hg}$ respectively. CV\% results for the physicochemical parameters varied from 2.19 to $15.05 \%$ of $\mathrm{pH}$ and $\mathrm{P}$, respectively. Results of low CV\% values for $\mathrm{pH}$ indicates particularly hydrogen concentrations in soil samples, similar results have also previously reported in researches for agricultural soils (Hausherr Lüder, Qin, Richner, Stamp, \& Noulas, 2018; López-Granados et al., 2002). Physicochemical parameters in soil samples, especially $\mathrm{Na}, \mathrm{P}$, and $\mathrm{EC}$ showed moderate variability, while $\mathrm{Ca}, \mathrm{K}, \mathrm{Mg}, \mathrm{OM}$, and total $\mathrm{N}$ showed low variability. For heavy metals, $\mathrm{CV} \%$ values higher than $10 \%$ were reported for $\mathrm{As}, \mathrm{Ba}, \mathrm{Cd}, \mathrm{Hg}$, and $\mathrm{Zn}$, indicating moderate variability for these heavy metals.

Results of skewness display a statistically nearly symmetrical distribution of soil parameters with minor positive or negative skews. For soil physicochemical parameters, the highest positively skewed parameter was the $\mathrm{pH}$ of value equals 1.28 , while the highest negatively skewed parameters were $\mathrm{OM}$ of value equals -0.64 . For heavy metals, the highest positively skewed metal was As (0.96), whereas the highest negatively skewed metal was $\mathrm{Pb}(-0.61)$. As shown in Table 1, kurtosis values for investigated parameters in soil samples reveal a moderately normal distribution for a majority of the concentration values.

The dataset presented in Table 1 also revealed that soil samples are relatively rich in available $\mathrm{P}$, its concentration ranges from 55.43 to $94.7 \mathrm{mg} / \mathrm{kg}$ which is much higher than the required minimum $\mathrm{P}$ concentration of $8.0 \mathrm{mg} / \mathrm{kg}$ in agricultural soils (Sillanpaa, 1990). Similarly, for the exchangeable cation K, concentrations in soil samples are ranging from 1432.2 to $1739.8 \mathrm{mg} / \mathrm{kg}$, indicate that soil samples are enriched with K as they exceed the critical limit for plant growth (Sillanpaa, 1990). High concentrations of $\mathrm{Ca}, \mathrm{K}$, and $\mathrm{K}$ were also observed in Table 1, indicating the nature of soil composition in the study area. The mean EC value $0.24 \mathrm{mS} / \mathrm{m}$ shows that the soil of the study area is non-saline, the soil salinity threshold is $4 \mathrm{dS} / \mathrm{m}$ (Shrivastava \& Kumar, 2015). Similarly, for the exchangeable cation $\mathrm{K}$, concentrations in soil samples are ranging from 1432.2 to $1739.8 \mathrm{mg} / \mathrm{kg}$, indicate that soil samples are enriched with $\mathrm{K}$ as they exceed the critical limit for plant growth (Sillanpaa, 1990). 
Table 1: Descriptive statistics of soil parameters

\begin{tabular}{|c|c|c|c|c|c|c|c|c|}
\hline Parameter & Min & Max & Mean & Median & $\begin{array}{l}\text { St. } \\
\text { Dev. }\end{array}$ & Skew. & Kurt. & $\mathrm{CV} \%$ \\
\hline \multicolumn{9}{|l|}{ Soil Parameters } \\
\hline $\mathrm{Ca}(\mathrm{mg} / \mathrm{kg})$ & 11328 & 15098 & 13092 & 12919 & 1148.1 & 0.25 & -0.97 & 8.77 \\
\hline $\mathrm{K}(\mathrm{mg} / \mathrm{kg})$ & 1432.2 & 1739.8 & 1590.7 & 1567.2 & 88.9 & 0.19 & -0.93 & 5.59 \\
\hline $\mathrm{Mg}(\mathrm{mg} / \mathrm{kg})$ & 2137.4 & 2834.1 & 2471.0 & 2445.5 & 178.1 & 0.36 & 0.12 & 7.21 \\
\hline $\mathrm{Na}(\mathrm{mg} / \mathrm{kg})$ & 142.50 & 217.35 & 172.89 & 169.95 & 22.96 & 0.45 & -0.96 & 13.28 \\
\hline $\mathrm{P}(\mathrm{mg} / \mathrm{kg})$ & 55.43 & 94.70 & 73.65 & 72.30 & 11.09 & 0.38 & -0.90 & 15.05 \\
\hline $\mathrm{pH}$ (pH degree) & 7.25 & 7.86 & 7.46 & 7.40 & 0.16 & 1.28 & 0.73 & 2.19 \\
\hline $\mathrm{OM}(\%)$ & 5.32 & 6.60 & 6.06 & 6.10 & 0.35 & -0.64 & -0.25 & 5.81 \\
\hline $\mathrm{EC}(\mathrm{mS} / \mathrm{m})$ & 0.20 & 0.32 & 0.24 & 0.23 & 0.03 & 1.02 & 0.49 & 13.43 \\
\hline Total N (\%) & 0.27 & 0.32 & 0.30 & 0.30 & 0.01 & -0.37 & -0.56 & 4.44 \\
\hline \multicolumn{9}{|l|}{ Heavy Metals } \\
\hline $\mathrm{Al}(\mathrm{mg} / \mathrm{kg})$ & 3674.00 & 5003.00 & 4216.56 & 4182.00 & 325.16 & 0.86 & 0.52 & 7.71 \\
\hline As $(\mathrm{mg} / \mathrm{kg})$ & 1.05 & 2.10 & 1.48 & 1.35 & 0.31 & 0.96 & -0.43 & 21.05 \\
\hline $\mathrm{Ba}(\mathrm{mg} / \mathrm{kg})$ & 48.32 & 72.43 & 58.07 & 57.54 & 5.51 & 0.61 & 0.76 & 9.48 \\
\hline $\mathrm{Cd}(\mathrm{mg} / \mathrm{kg})$ & 0.39 & 0.60 & 0.50 & 0.50 & 0.06 & -0.10 & -0.54 & 11.52 \\
\hline Co $(\mathrm{mg} / \mathrm{kg})$ & 2.32 & 2.76 & 2.53 & 2.54 & 0.14 & 0.02 & -1.38 & 5.71 \\
\hline $\mathrm{Cr}(\mathrm{mg} / \mathrm{kg})$ & 10.15 & 12.95 & 11.66 & 11.60 & 0.82 & -0.08 & -1.01 & 7.07 \\
\hline $\mathrm{Cu}(\mathrm{mg} / \mathrm{kg})$ & 3.12 & 3.57 & 3.33 & 3.32 & 0.14 & 0.21 & -1.29 & 4.19 \\
\hline $\mathrm{Fe}(\mathrm{mg} / \mathrm{kg})$ & 3365.00 & 4287.15 & 3912.54 & 3928.75 & 235.11 & -0.30 & -0.26 & 6.01 \\
\hline $\mathrm{Hg}(\mathrm{mg} / \mathrm{kg})$ & 0.21 & 0.65 & 0.48 & 0.50 & 0.12 & -0.48 & -0.39 & 24.95 \\
\hline $\mathrm{Li}(\mathrm{mg} / \mathrm{kg})$ & 29.70 & 34.65 & 31.82 & 31.80 & 1.50 & 0.29 & -1.00 & 4.71 \\
\hline $\mathrm{Mn}(\mathrm{mg} / \mathrm{kg})$ & 109.40 & 127.80 & 119.45 & 119.55 & 4.18 & -0.11 & 0.09 & 3.50 \\
\hline $\mathrm{Ni}(\mathrm{mg} / \mathrm{kg})$ & 18.30 & 22.95 & 20.79 & 20.40 & 1.44 & 0.20 & -1.23 & 6.93 \\
\hline $\mathrm{Pb}(\mathrm{mg} / \mathrm{kg})$ & 5.30 & 6.30 & 5.93 & 5.95 & 0.29 & -0.61 & -0.26 & 4.82 \\
\hline
\end{tabular}




\begin{tabular}{lllllllll}
\hline $\mathrm{Sr}(\mathrm{mg} / \mathrm{kg})$ & 109.30 & 126.10 & 117.07 & 116.60 & 4.95 & 0.30 & -1.05 & 4.23 \\
$\mathrm{~V}(\mathrm{mg} / \mathrm{kg})$ & 8.00 & 9.75 & 8.83 & 8.87 & 0.51 & 0.09 & -1.03 & 5.80 \\
$\mathrm{Zn}(\mathrm{mg} / \mathrm{kg})$ & 18.32 & 29.50 & 22.51 & 22.81 & 3.19 & 0.40 & -0.89 & 14.19 \\
\hline
\end{tabular}

\subsection{Relationships between Soil Properties and Heavy Metals}

\subsubsection{Statistical Analysis}

Results obtained by Pearson's correlation matrix CM are shown in Table 2, significant relationships among soil parameters and heavy metals can be observed. Regularly, in CM analysis, a correlation coefficient that is closer to 1.0 is indicating a strong relationship between the assessed variables. At $\mathrm{P}$ $<0.01$, several significant correlation coefficients $>0.3$ are existing.

As seen in Table 2, among the soil properties parameters, some significant positive correlation coefficients are existing, $(\mathrm{Na}-$ available $\mathrm{P})$, and $(\mathrm{pH}-\mathrm{OM})$. On the other hand, several negative correlation coefficients are existing: $\mathrm{K}$ with $\mathrm{Mg}, \mathrm{Na}$, and available $\mathrm{P} . \mathrm{Ca}$ has a significant negative correlation with soil $\mathrm{pH}$ and $\mathrm{OM}$. negative $\mathrm{pH}$ correlations with $\mathrm{Ca}, \mathrm{Mg}, \mathrm{Na}, \mathrm{EC}$, and total $\mathrm{N}$ were observed, similar correlations were also reported between $\mathrm{pH}$ and other soil parameters and micronutrients (Chamannejadian, Moezzi, Sayyad, Jahangiri, \& Jafarnejadi, 2011; Lindsay, 2001).

Table 2 reveals also many significant positive correlation coefficients, $r>0.3$ at $p<0.01$, between heavy metals and soil properties: (K-Co); (K-Zn); (Na-Li); (Na-Pb); (available P-As); (available P$\mathrm{Fe}$ ); (available P-Sr); (pH-Zn); (EC-Al); (EC-Hg); (T.N.-Cd); (T.N.-Co); (T.N.-Hg); and (T.N.- Sr). Similarly, negative significant correlation coefficients $r<-0.3$ at $p<0.01$, were observed between heavy metals and soil properties: (K-As); (Mg-Co); (available P-V); (pH-V); (OM-Cd); (OM-Cr); $(\mathrm{OM}-\mathrm{Cu})$; (EC-Sr); and (EC-Zn).

Significant correlations between ( $\mathrm{N}$ with $\mathrm{Cu}$ and $\mathrm{Cd}$ ) and ( $\mathrm{P}$ with $\mathrm{Fe}$ ) were also reported by (KavitaVerma \& Pandey, 2019). Positive correlation coefficients, (P with $\mathrm{Zn}$ ) and (P with $\mathrm{Pb}$ ), and negative correlation coefficients, $(\mathrm{pH}$ with $\mathrm{Pb}$ ) and $(\mathrm{pH}$ with $\mathrm{Cu}$ ), were also reported by (Nan, Zhao, $\mathrm{Li}, \mathrm{Chen}, \& \mathrm{Sun}, 2002)$. The negative correlation between $\mathrm{Cu}$ and $\mathrm{pH}$ suggests that an increase in $\mathrm{Cu}$ concentration in the soil causes a considerable decrease in $\mathrm{pH}$ of that soil, or high $\mathrm{pH}$ level in the soil leads to a decrease in $\mathrm{Cu}$ solubility in soil (Sürücü, Ahmed, Günal, \& Budak, 2019). The negative correlations between $\mathrm{OM}$ and some heavy metals indicate that the presence of heavy metals is deteriorating OM of soils. Therefore, from the observed relationships of soil properties with heavy metals, it is clear that soil properties are susceptible to be altered in the presence of particular heavy metals (Adriano, 2001). Results of CM also suggest that the origin of some heavy metals is most probably is the natural composition soils or rocks of the area (Mileusnić et al., 2014), as those heavy metals have significant correlations with soil properties, with taking in account the contribution of anthropogenic activities in heavy metals occurrence in the study area. Although previous studies in the literature stated strong negative correlations between $\mathrm{pH}$ and various heavy metals in soils, this study suggests that only weak negative correlations are existing with specific heavy metals, no evidence could be detected in the CM may agree with those earlier findings. 
Table 2: Correlation matrix among soil physicochemical properties and interrelationships of soil physicochemical properties with heavy metals

\begin{tabular}{|c|c|c|c|c|c|c|c|c|c|}
\hline Variables & $\overline{\mathrm{Ca}}$ & $\overline{\mathrm{K}}$ & $\mathrm{Mg}$ & $\mathrm{Na}$ & $\bar{P}$ & $\overline{\mathrm{pH}}$ & $\overline{\mathrm{OMM}}$ & $\overline{\mathrm{EC}}$ & T.N. \\
\hline $\mathrm{Ca}$ & 1.00 & & & & & & & & \\
\hline K & 0.17 & 1.00 & & & & & & & \\
\hline $\mathrm{Mg}$ & 0.12 & -0.32 & 1.00 & & & & & & \\
\hline $\mathrm{Na}$ & -0.28 & -0.33 & -0.03 & 1.00 & & & & & \\
\hline $\mathrm{P}$ & 0.14 & -0.31 & 0.24 & 0.31 & 1.00 & & & & \\
\hline $\mathrm{pH}$ & -0.08 & 0.22 & -0.13 & -0.20 & 0.16 & 1.00 & & & \\
\hline $\mathrm{OM}$ & 0.03 & 0.04 & -0.15 & 0.18 & 0.16 & 0.33 & 1.00 & & \\
\hline EC & -0.10 & -0.08 & -0.21 & -0.02 & -0.26 & -0.14 & 0.11 & 1.00 & \\
\hline T.N. & -0.10 & 0.00 & -0.21 & 0.15 & -0.10 & -0.04 & -0.23 & 0.07 & 1.00 \\
\hline $\mathrm{Al}$ & 0.32 & 0.06 & -0.27 & -0.05 & -0.21 & -0.28 & -0.21 & 0.31 & 0.08 \\
\hline As & -0.18 & -0.30 & 0.11 & 0.10 & 0.35 & 0.05 & -0.23 & -0.11 & -0.07 \\
\hline $\mathrm{Ba}$ & 0.01 & -0.06 & 0.20 & 0.01 & 0.17 & 0.18 & 0.14 & -0.06 & -0.01 \\
\hline $\mathrm{Cd}$ & 0.04 & 0.06 & 0.10 & 0.16 & 0.19 & 0.00 & -0.40 & 0.07 & 0.40 \\
\hline Co & -0.13 & 0.43 & -0.33 & -0.08 & -0.26 & -0.01 & -0.12 & 0.08 & 0.38 \\
\hline $\mathrm{Cr}$ & 0.11 & 0.29 & -0.01 & -0.25 & -0.08 & -0.10 & -0.39 & -0.25 & -0.22 \\
\hline $\mathrm{Cu}$ & 0.24 & -0.02 & 0.03 & 0.11 & 0.12 & -0.23 & -0.30 & -0.07 & 0.47 \\
\hline $\mathrm{Fe}$ & 0.02 & 0.00 & 0.10 & 0.15 & 0.38 & 0.22 & -0.20 & -0.28 & -0.10 \\
\hline $\mathrm{Hg}$ & -0.18 & 0.11 & -0.08 & -0.02 & -0.07 & -0.17 & -0.07 & 0.35 & 0.31 \\
\hline $\mathrm{Li}$ & -0.08 & -0.26 & 0.27 & 0.31 & 0.24 & -0.08 & 0.05 & -0.26 & 0.09 \\
\hline Mn & 0.26 & 0.01 & 0.24 & -0.05 & 0.23 & -0.13 & -0.13 & 0.11 & 0.12 \\
\hline $\mathrm{Ni}$ & 0.21 & 0.12 & 0.04 & -0.06 & 0.03 & -0.04 & 0.00 & -0.18 & 0.24 \\
\hline $\mathrm{Pb}$ & 0.22 & -0.28 & 0.17 & 0.33 & 0.13 & -0.36 & 0.02 & -0.07 & -0.18 \\
\hline $\mathrm{Sr}$ & -0.06 & 0.19 & -0.10 & -0.01 & 0.43 & 0.24 & 0.21 & -0.37 & 0.32 \\
\hline V & 0.22 & 0.14 & 0.23 & -0.27 & -0.52 & -0.21 & -0.32 & 0.16 & 0.19 \\
\hline
\end{tabular}




\begin{tabular}{llllllllll}
$\mathrm{Zn}$ & 0.24 & 0.30 & 0.05 & -0.17 & 0.28 & 0.47 & -0.04 & -0.35 & -0.18 \\
\hline
\end{tabular}

The CM showed certain significant relationships between certain soil properties and heavy metals, to investigate interrelationships between those parameters further statistical analysis has been performed using AHC. The AHC was submitted in this work based on Ward's method with Euclidean distance for measuring the dissimilarity. AHC classified the relation between soil properties and heavy metals into several main groups. The internal cluster homogeneity was established according to the similarity among concentrations of property parameters and heavy metals in soil.

\subsubsection{Multivariate Statistical Analysis}

Three main clusters have been recognized as shown in Figure 2. The dendrogram of AHC exhibits three distinctive correlations of soil properties with heavy metals: cluster 1, dominated by $\mathrm{Mg}, \mathrm{pH}$, $\mathrm{OM}$, and $\mathrm{P}$ with certain heavy metals such as $\mathrm{Cd}, \mathrm{Cr}, \mathrm{Fe}$, and $\mathrm{Zn}$; cluster 2 relates $\mathrm{Na}$ with heavy metals for $\mathrm{Pb}$ and $\mathrm{Li}$; cluster 3 involves soil properties of T.N., K, Ca with heavy metals of $\mathrm{Cu}, \mathrm{Ni}$, $\mathrm{Co}, \mathrm{Hg}, \mathrm{V}$, and $\mathrm{Al}$.

AHC analysis reveals complex interrelationships between soil properties and heavy metals in the study area that are divided into three classes. Heavy metals in clusters 3 have that have significant relationships with $(\mathrm{Ca}$ and $\mathrm{Al})$, and at the same time have a significant relationship with $\mathrm{Hg}$, wellknown heavy metals of an anthropogenic origin. These interrelationships suggest that clusters 3 is representing a mixed source of heavy metals, natural and anthropogenic. Cluster 2 represents $\mathrm{Pb}, \mathrm{Li}$, and $\mathrm{Na}$ that have no significant relationships with the remaining soil properties and heavy metals. While cluster 1 involves heavy metals that have significant relationships with ( $\mathrm{Mg}$ and $\mathrm{Fe}$ ), therefore, cluster 1 suggest that the interrelationship between $\mathrm{Fe}$ and $\mathrm{Mg}$ with certain heavy metals might be originated as natural weathering of parent materials in the study area. Fe is permanently considered as free from anthropogenic effects and exists at abundant levels in the crust (Liu, Yang, Yun, Zhang, \& Wang, 2015). Soils of the study area are belonging to the low rainfall region are containing more $\mathrm{Mg}$ or $\mathrm{Ca}$ carbonates in their profile (Azeez \& Rahimi, 2017). In cluster 3, heavy metals such as $\mathrm{Hg}, \mathrm{Cu}, \mathrm{Ni}, \mathrm{Co}$, and $\mathrm{V}$ have a significant impact on soil properties of T.N., $\mathrm{Ca}, \mathrm{K}$, and $\mathrm{EC}$, indicating an excessive application of pesticides and inorganic fertilizers that containing such heavy metals in Iraqi agricultural areas (Al-Tamimi \& Ali, 2018). 


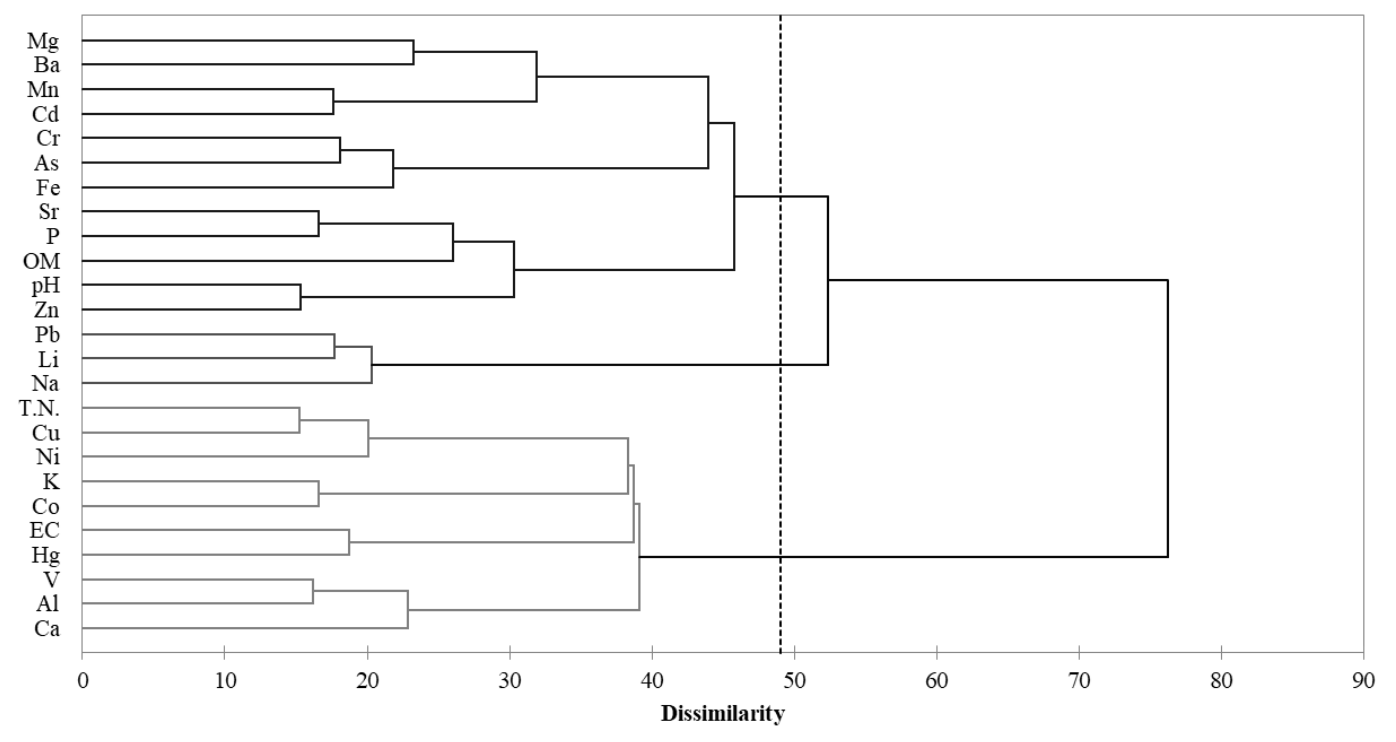

Figure 2: Dendrogram for inter-relationships between soil physicochemical properties with heavy metals in the study area

MCA was submitted for further investigation of the interrelationships between soil property parameters and heavy metals in the study area. MCA was application was based on normalized values of correlations established between two groups. MCA in this research aids to distinguish interrelationships among soil property parameters in their group, and also with each heavy metal in the second group. MCA results show, for $73.82 \%$ of the total variance of relationships dataset in soil, correlations can be represented by four main factors: factors F1, F2, F3, and F4 are accounting for $26.40 \%, 18.62 \%, 16.40 \%$, and $12.40 \%$ of the total variance of interrelationships between soil parameters and heavy metals, respectively. MCA analysis is illustrated in Figure 3, where $73.82 \%$ of total variance was displayed as symmetric plots.

Figure 3, for $73.82 \%$ of the total variance, shows that soil properties are significantly impacted by the investigated heavy metals. T.N. is strongly correlated with $\mathrm{Cu}, \mathrm{Ni}$, and $\mathrm{Hg}$ in soils of the study area. Similarly, it observed that $\mathrm{pH}$ is highly correlated with $\mathrm{Zn}$, and also $\mathrm{Ca}$ is highly correlated with Al. Likewise, $\mathrm{P}$ is strongly correlated with $\mathrm{Fe}$ and $\mathrm{V}$. At all times, $\mathrm{Cu}$ is negatively correlated with $\mathrm{P}$. Mostly, $\mathrm{Na}$ has a high correlation with $\mathrm{Pb}$, indicating its agreement with AHC results. OM is highly correlated to $\mathrm{Cd}$ and $\mathrm{Cr}$ in a later stage, similar findings are expected for $\mathrm{OM}$, as $\mathrm{OM}$ bounds with heavy metals in soil (Zeng et al., 2011).

Figure 3 (a) displays $45.02 \%$ of the total variance in relationships, $\mathrm{Ca}, \mathrm{EC}$, and $\mathrm{pH}$ was strongly correlated with $\mathrm{Zn}$, and $\mathrm{Al}$. On the other hand, $\mathrm{Co}, \mathrm{Cr}$, and $\mathrm{Cd}$ are negatively correlated to $\mathrm{pH}$, suggesting that the existence of such heavy metals leading to a decrease in $\mathrm{pH}$.

In Figure 3 (b), representing $28.80 \%$ of total relationships, it can be seen that OM is highly related to $\mathrm{Cd}$, indicating that always there are certain heavy metals in soils that are linked with OM (Jones \& Jacobsen, 2009). It is worth pointing out that there is no inconsistency between results of AHC and MCA, MCA links each soil property to heavy metals regardless of their source, whereas AHC categorizes relationships between soil properties and heavy metals with considering their sources. 

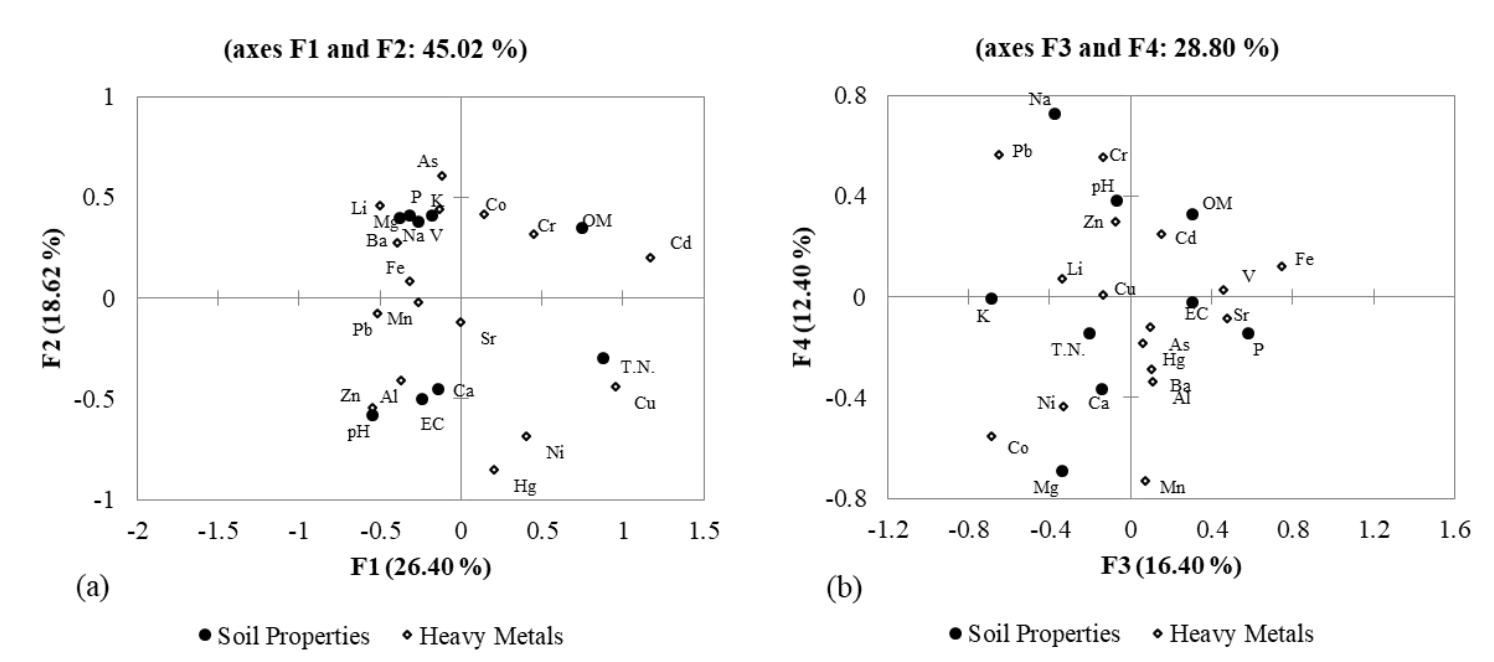

Figure 3: Symmetric plots based on MCA, (a) for factors F1 and F2 and represents $45.02 \%$ of total variance between soil properties and heavy metals, (b) for factors F3 and F4 and represents $28.80 \%$ of total variance between soil properties and heavy metals.

Factorial analysis FA has also been applied in this work to further categorize relationships of soil properties with heavy metals. From AHC results, there are three distinct types of soil properties relationships with heavy metals: soil properties linked strongly to heavy metals of natural origin, represented by cluster 1; soil properties highly correlated with heavy metals of heavy metals came from anthropogenic sources; limited relationships between soil properties with heavy metals.

Greatly, the first category was dominated by Fe, representing the natural composition of soils in the study area, the second group is highly dominated by $\mathrm{Hg}$, indicating the impact of anthropogenic activities on soil properties. FA was conducted by using Varimax rotation with Kaiser Normalization, whereas a significant enhancement in percentages of factors loading and eigenvalue was achieved after rotation. After rotation, factors with high eigenvalues are taken into account, where nine factors were extracted, representing $66.28 \%$ of the total variance of the dataset as shown in Table 3. 
Table 3: Correlations between variables and factors after Varimax rotation, by using FA*

\begin{tabular}{|c|c|c|c|c|c|c|c|c|c|}
\hline & D1 & D2 & D3 & D4 & D5 & D6 & D7 & D8 & D9 \\
\hline $\mathrm{Ca}$ & -0.09 & 0.15 & 0.15 & 0.00 & 0.72 & -0.04 & -0.01 & -0.14 & 0.05 \\
\hline K & -0.08 & 0.71 & 0.12 & -0.11 & 0.06 & 0.11 & 0.13 & -0.04 & -0.21 \\
\hline $\mathrm{Mg}$ & 0.03 & -0.14 & -0.01 & 0.10 & 0.11 & -0.10 & 0.00 & -0.05 & 0.97 \\
\hline $\mathrm{Na}$ & 0.18 & -0.64 & 0.04 & -0.12 & -0.12 & 0.06 & 0.13 & -0.06 & -0.10 \\
\hline $\mathrm{P}$ & 0.78 & -0.33 & 0.14 & -0.09 & 0.27 & -0.12 & 0.13 & 0.00 & 0.11 \\
\hline $\mathrm{pH}$ & 0.37 & 0.37 & 0.01 & -0.24 & -0.17 & -0.19 & -0.05 & -0.17 & -0.05 \\
\hline $\mathrm{OM}$ & 0.17 & -0.02 & -0.09 & -0.95 & 0.01 & -0.06 & -0.23 & 0.02 & -0.07 \\
\hline EC & -0.34 & -0.11 & -0.29 & -0.07 & 0.03 & -0.10 & 0.11 & 0.40 & -0.21 \\
\hline T.N. & -0.18 & -0.10 & 0.49 & 0.10 & -0.27 & -0.04 & 0.51 & 0.13 & -0.16 \\
\hline $\mathrm{Al}$ & -0.52 & -0.07 & 0.06 & 0.11 & 0.36 & -0.03 & -0.01 & 0.10 & -0.31 \\
\hline As & 0.51 & -0.17 & -0.07 & 0.38 & -0.09 & 0.28 & -0.03 & -0.03 & 0.10 \\
\hline $\mathrm{Ba}$ & 0.06 & 0.01 & 0.14 & -0.09 & 0.03 & -0.79 & -0.01 & -0.08 & 0.13 \\
\hline $\mathrm{Cd}$ & 0.13 & -0.05 & 0.00 & 0.23 & 0.01 & -0.15 & 0.69 & 0.02 & 0.02 \\
\hline Co & -0.22 & 0.28 & 0.11 & -0.10 & -0.16 & 0.46 & 0.61 & -0.11 & -0.22 \\
\hline $\mathrm{Cr}$ & 0.18 & 0.40 & -0.24 & 0.44 & 0.20 & 0.50 & 0.03 & -0.08 & 0.00 \\
\hline $\mathrm{Cu}$ & -0.09 & -0.18 & 0.70 & 0.18 & 0.19 & 0.01 & 0.21 & 0.10 & -0.02 \\
\hline $\mathrm{Fe}$ & 0.51 & 0.06 & -0.19 & 0.27 & -0.04 & -0.14 & 0.13 & -0.37 & 0.02 \\
\hline $\mathrm{Hg}$ & -0.07 & 0.04 & 0.22 & 0.03 & -0.11 & 0.06 & 0.08 & 0.92 & -0.01 \\
\hline $\mathrm{Li}$ & 0.17 & -0.38 & 0.36 & -0.06 & -0.15 & 0.45 & -0.20 & 0.00 & 0.24 \\
\hline $\mathrm{Mn}$ & 0.07 & 0.04 & -0.08 & 0.01 & 0.44 & 0.08 & 0.55 & 0.25 & 0.23 \\
\hline $\mathrm{Ni}$ & -0.07 & 0.09 & 0.71 & -0.04 & 0.16 & -0.06 & -0.14 & 0.01 & 0.03 \\
\hline $\mathrm{Pb}$ & -0.10 & -0.50 & 0.11 & -0.03 & 0.43 & 0.49 & -0.18 & -0.05 & 0.14 \\
\hline $\mathrm{Sr}$ & 0.35 & 0.19 & 0.58 & -0.21 & -0.15 & -0.14 & 0.13 & 0.10 & -0.04 \\
\hline V & -0.64 & 0.15 & 0.09 & 0.21 & 0.16 & -0.01 & 0.03 & -0.03 & 0.18 \\
\hline $\mathrm{Zn}$ & 0.52 & 0.39 & 0.28 & 0.13 & 0.21 & 0.03 & -0.17 & -0.31 & 0.05 \\
\hline
\end{tabular}


"correlations $\geq 0.4$ were considered significant and presented in bold.

Table 3 for FA results shows a great agreement with the results of AHC, proposing that certain soil properties are directly bonded to heavy metals of natural origins, on the other hand, the remaining soil properties are significantly linked to heavy metals of anthropogenic origins. FA results show that strong correlations within rotated factor D1 for Fe and confirms particularly that this factor represents relationships between physicochemical soil properties with heavy metals that exist naturally as abundant minerals of earth's crust. D1 is explaining mainly variation of Fe in soil samples, therefore D1 is, at the same time, representing the highest values of that heavy metal. The rotated factor D8 represents relationships between soil properties with well-known heavy metals generated from anthropogenic sources of $\mathrm{Hg}$.

\subsubsection{Geospatial Analysis}

The spatial distribution of soil properties relationships and heavy metals in the study area was displayed by showing scores of the factor D8 over the study area using Kriging interpolation, ArcGIS 10.6 software, as seen in Figure 4. It was confirmed by FA results that D8 explains specifically relationships of soil properties with heavy metals originated from anthropogenic activities, therefore higher values of interpolated data for D8 would display the spatial relationships of soil properties that are mainly with heavy metals accumulated due to anthropogenic activities, and therefore, soils with lower values of D8 interpolated data are representing relationships of soil properties with abundant heavy metals of earth's crust composition.

From Figure 4 it can be observed that in some of the middle regions of the study area soil physicochemical properties are greatly impacted by heavy metals that mostly originated from anthropogenic activities. These findings are supported by the fact that these parts are close to the main road passing through the area. Most probably, these parts are highly affected by most probably by atmospheric deposition of heavy metals from vehicle exhausts, and excessive fertilizers and pesticides applications as well, these findings agree with results reported by (Sürücü, Mohammad, Günal, \& Budak, 2018). 


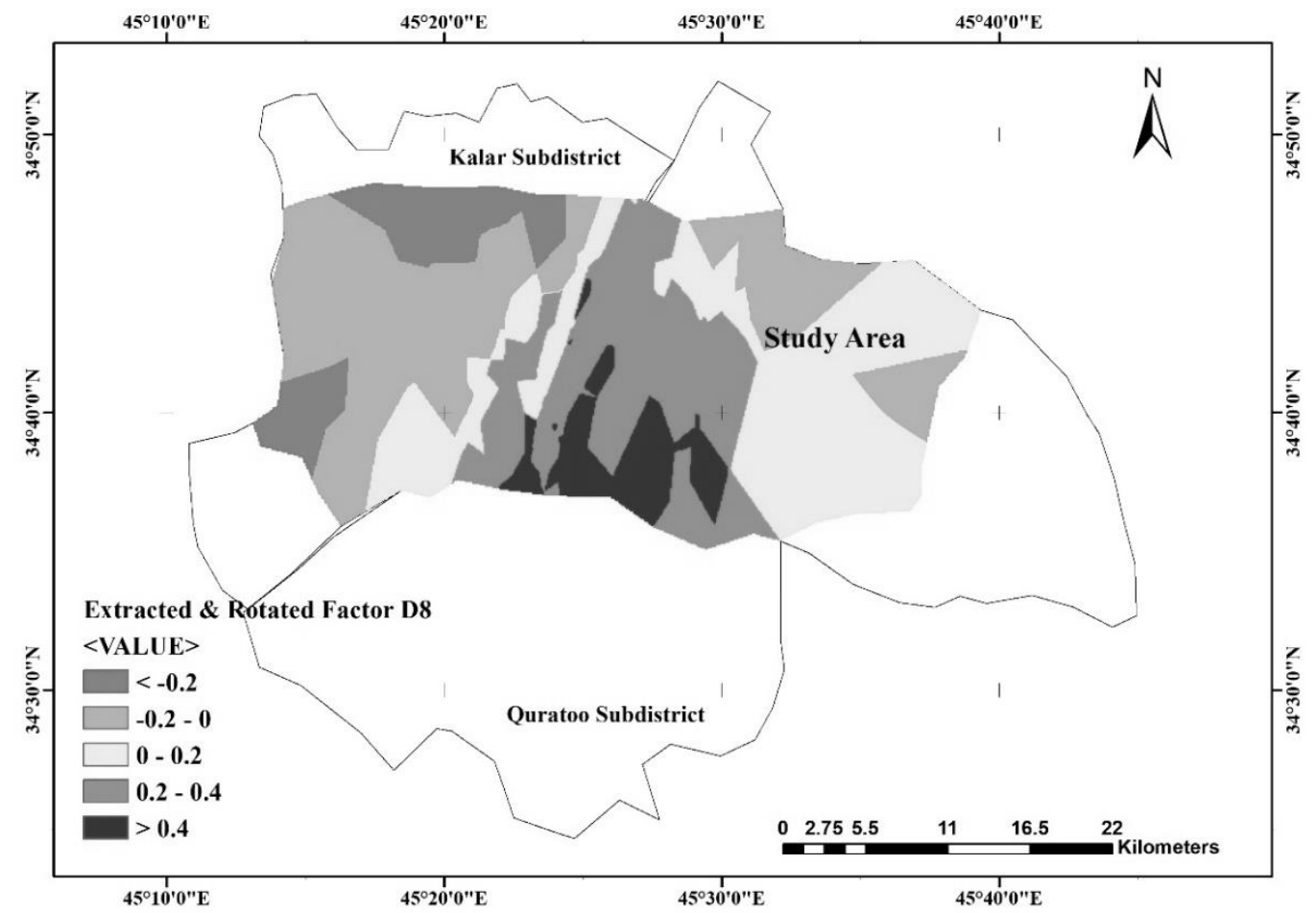

Figure 4: Graph for scores of the rotated factor D8 calculated by FA for soil samples of the study area, obtained by Kriging interpolation, in ArcGIS software.

\section{Conclusions}

In the present work, multivariate and geospatial statistics were performed on the obtained dataset of soil samples collected from the study area to realize and to establish a reliable prediction for relationships between soil physicochemical properties and heavy metals. In the study area, interrelationships between soil physicochemical properties with important heavy metals have been discovered using multivariate statistical methods such as CM (Pearson), MCA, AHC with Ward's, and Euclidean methods, FA with Varimax rotation and Kaiser Normalization. Investigated soil samples showed varying correlations with heavy metals. AHC was able to reorder these correlations into three distinctive types in terms of heavy metals sources. However, MCA showed strong relationships were occurring between T.N. and $\mathrm{Cu}, \mathrm{Ni}$, and $\mathrm{Hg}$. Also, $\mathrm{pH}$ was highly correlated with $\mathrm{Zn}$. Ca was highly correlated with Al. In agreement with AHC results, the extracted factor after rotation D8 was representing heavy metals that originated from anthropogenic sources, the factor is mainly predominated by $\mathrm{Hg}$. Kriging interpolation was performed to display the spatial distribution of soil properties relationships with heavy metals. The spatial distribution map showed that soil properties in the middle parts of the study area are more impacted by the heavy metals generated from anthropogenic activities, most probably from vehicle exhausts. This work assists to evaluate the types of relationships between heavy metals and some physicochemical soil properties in the study area, by which more improvements of environmental programs of land sustainability can be achieved. 


\section{References}

Adriano, D. C. (2001). Trace elements in terrestrial environments: biogeochemistry, bioavailability and risks of metals (n. edn. Ed.). New York: Springer.

Al-Tamimi, O. S., \& Ali, M. J. (2018). Geo-Environmental Evaluation of Shewasoor Soil, Kirkuk/NE Iraq. Kirkuk University Journal for Scientific Studies, 13(2), 82-100.

Azeez, S. N., \& Rahimi, I. (2017). Distribution of Gypsiferous Soil Using Geoinformatics Techniques for Some Aridisols in Garmian, Kurdistan Region-Iraq. Kurdistan Journal of Applied Research, 2(1), 57-64.

Behera, S. K., \& Shukla, A. K. (2015). Spatial Distribution of Surface Soil Acidity, Electrical Conductivity, Soil Organic Carbon Content and Exchangeable Potassium, Calcium and Magnesium in Some Cropped Acid Soils of India. Land Degradation \& Development, 26(1), 71-79. doi:10.1002/ldr.2306

Bhunia, G. S., Shit, P. K., \& Maiti, R. (2018). Comparison of GIS-based interpolation methods for spatial distribution of soil organic carbon (SOC). Journal of the Saudi Society of Agricultural Sciences, 17(2), 114-126. doi: https://doi.org/10.1016/j.jssas.2016.02.001

Bremner, J. M., \& Mulvaney, C. (1983). Nitrogen-total. Methods of soil analysis: Part 2 chemical and microbiological properties, 9, 595-624.

Budak, M. (2018). Importance of Spatial Soil Variability for Land Use Planning of a Farmland in a Semi-Arid Region. Fresenius Environment Bulletin, 27(7), 5053-5065.

Buringh, P. (1960). Soils and soil conditions in Iraq: Republic of Iraq, Ministry of Agriculture, Directorate of Agricultural Research and Projects.

Castrignanò, A., Giugliarini, L., Risaliti, R., \& Martinelli, N. (2000). Study of spatial relationships among some soil physico-chemical properties of a field in central Italy using multivariate geostatistics. Geoderma, 97(1), 39-60. doi: https://doi.org/10.1016/S0016-7061(00)000252

Chamannejadian, A., Moezzi, A., Sayyad, G., Jahangiri, A., \& Jafarnejadi, A. (2011). Spatial distribution of lead in calcareous soils and rice seeds of Khuzestan, Iran. Malaysian Journal of Soil Science, 15, 115-125.

Chen, F., \& Pu, L.-j. (2007). Relationship between heavy metals and basic properties of agricultural soils in Kunshan County. Soils, 39, 291-296.

Davies, B. E. (1992). Inter-relationships between soil properties and the uptake of cadmium, copper, lead and zinc from contaminated soils by radish (Raphanus sativus L.). Water, Air, and Soil Pollution, 63(3), 331-342. doi:10.1007/BF00475500

Galford, G. L., Soares-Filho, B., \& Cerri, C. E. P. (2013). Prospects for land-use sustainability on the agricultural frontier of the Brazilian Amazon. Philosophical Transactions of the Royal Society B: Biological Sciences, 368(1619), 20120171. doi: doi:10.1098/rstb.2012.0171

Garmian Region Agriculture Department. (2017). Unpublished reports.

Gutiérrez, C., Fernández, C., Escuer, M., Campos-Herrera, R., Beltrán Rodríguez, M. E., Carbonell, G., \& Rodríguez Martín, J. A. (2016). Effect of soil properties, heavy metals and emerging contaminants in the soil nematodes diversity. Environmental Pollution, 213, 184-194. doi: https://doi.org/10.1016/j.envpol.2016.02.012

Hausherr Lüder, R.-M., Qin, R., Richner, W., Stamp, P., \& Noulas, C. (2018). Spatial variability of selected soil properties and its impact on the grain yield of oats (Avena sativa L.) in small fields. Journal of Plant Nutrition, 41(19), 2446-2469. doi:10.1080/01904167.2018.1527935

Iraqi Meteorological Organization and Seismology. (2010). Unpublished climate reports.

Jones, C., \& Jacobsen, J. (2009). Micronutrients: cycling, testing and fertilizer recommendations. Nutr. Manage. Module, 7, 2-4.

KavitaVerma, \& Pandey, J. (2019). Heavy metal accumulation in surface sediments of the Ganga River (India): speciation, fractionation, toxicity, and risk assessment. Environmental Monitoring and Assessment, 191(7), 414. doi:10.1007/s10661-019-7552-7

Khalifa, M., \& Gad, A. (2018). Assessment of Heavy Metals Contamination in Agricultural Soil of 
Southwestern Nile Delta, Egypt. Soil and Sediment Contamination: An International Journal, 27(7), 619-642. doi:10.1080/15320383.2018.1498445

Kurdistan Region Statistics/ Garmian Office. (2018). Unpublished report. Erbil, Iraq.

Lagacherie, P., \& McBratney, A. B. (2006). Chapter 1 Spatial soil information systems and spatial soil inference systems: Perspectives for digital soil mapping. In P. Lagacherie, A. B. McBratney, \& M. Voltz (Eds.), Developments in Soil Science (Vol. 31, pp. 3-22): Elsevier. Lindsay, W. L. (2001). Chemical Equilibria in Soils: Blackburn Press.

Liu, M., Yang, Y., Yun, X., Zhang, M., \& Wang, J. (2015). Concentrations, distribution, sources, and ecological risk assessment of heavy metals in agricultural topsoil of the Three Gorges Dam region, China. Environmental Monitoring and Assessment, 187(3), 147. doi:10.1007/s10661-015-4360-6

López-Granados, F., Jurado-Expósito, M., Atenciano, S., García-Ferrer, A., Sánchez de la Orden, M., \& García-Torres, L. (2002). Spatial variability of agricultural soil parameters in southern Spain. Plant and Soil, 246(1), 97-105. doi:10.1023/A:1021568415380

Mileusnić, M., Mapani, B. S., Kamona, A. F., Ružičić, S., Mapaure, I., \& Chimwamurombe, P. M. (2014). Assessment of agricultural soil contamination by potentially toxic metals dispersed from improperly disposed tailings, Kombat mine, Namibia. Journal of Geochemical Exploration, 144, 409-420. doi: https://doi.org/10.1016/j.gexplo.2014.01.009

Muhaimeed, A. S., Saloom, A., Saleim, K., \& Alaane, K. (2014). Classification and Distribution of Iraqi Soils. International Journal of Agriculture Innovations and Research, 2(6), 997 1002.

Nan, Z., Zhao, C., Li, J., Chen, F., \& Sun, W. (2002). Relations Between Soil Properties and Selected Heavy Metal Concentrations in Spring Wheat (Triticum aestivum L.) Grown in Contaminated Soils. Water, Air, and Soil Pollution, 133(1), 205-213. doi:10.1023/A:1012962604095

Savci, S. (2012). An agricultural pollutant: chemical fertilizer. International Journal of Environmental Science and Development, 3(1), 73.

Shit, P. K., Bhunia, G. S., \& Maiti, R. (2016). Spatial analysis of soil properties using GIS based geostatistics models. Modeling Earth Systems and Environment, 2(2), 107. doi:10.1007/s40808-016-0160-4

Shrivastava, P., \& Kumar, R. (2015). Soil salinity: A serious environmental issue and plant growth promoting bacteria as one of the tools for its alleviation. Saudi Journal of Biological Sciences, 22(2), 123-131. doi: https://doi.org/10.1016/j.sjbs.2014.12.001

Sillanpaa, M. (1990). Micronutrient assessment at the country level: An international study. In (pp. 216 pp.).

Storer, D. A. (1984). A simple high sample volume ashing procedure for determination of soil organic matter. Communications in Soil Science and Plant Analysis, 15(7), 759-772. doi:10.1080/00103628409367515

Sungur, A., Soylak, M., \& Ozcan, H. (2014). Investigation of heavy metal mobility and availability by the BCR sequential extraction procedure: relationship between soil properties and heavy metals availability. Chemical Speciation \& Bioavailability, 26(4), 219-230. doi:10.3184/095422914X14147781158674

Sürücü, A., Ahmed, T. K., Günal, E., \& Budak, M. (2019). Spatial variability of some soil properties in an agricultural field of Halabja City of Sulaimani Governorate, Iraq. Fresenius Environment Bulletin, 28(1), 193-206.

Sürücü, A., Mohammad, D. M., Günal, E., \& Budak, M. (2018). Concentration of heavy metals in soils along three major roads of Sulaimani, Northeast Iraq.

Uchimiya, M., Klasson, K. T., Wartelle, L. H., \& Lima, I. M. (2011). Influence of soil properties on heavy metal sequestration by biochar amendment: 1 . Copper sorption isotherms and the release of cations. Chemosphere, 82(10), 1431-1437. doi: https://doi.org/10.1016/j.chemosphere.2010.11.050

Usowicz, B., \& Lipiec, J. (2017). Spatial variability of soil properties and cereal yield in a cultivated field on sandy soil. Soil and Tillage Research, 174, 241-250. doi: 
https://doi.org/10.1016/j.still.2017.07.015

Valladares, G. S., Camargo, O. A. d., Carvalho, J. R. P. d., \& Silva, A. M. C. (2009). Assessment of heavy metals in soils of a vineyard region with the use of principal component analysis. Scientia Agricola, 66(3), 361-367.

Vega, F. A., Covelo, E. F., Andrade, M. L., \& Marcet, P. (2004). Relationships between heavy metals content and soil properties in minesoils. Analytica Chimica Acta, 524(1), 141-150. doi: https://doi.org/10.1016/j.aca.2004.06.073

Zeng, F., Ali, S., Zhang, H., Ouyang, Y., Qiu, B., Wu, F., \& Zhang, G. (2011). The influence of pH and organic matter content in paddy soil on heavy metal availability and their uptake by rice plants. Environmental Pollution, 159(1), 84-91. doi:

https://doi.org/10.1016/j.envpol.2010.09.019 